\title{
ARTICLES
}

\section{KNOWLEDGE ON BIO-MEDICAL WASTE MANAGEMENT AMONG NURSING STUDENTS}

Dr. Mandeep Kaur* \& Ms. Kiranjit Kaur**

*Associate Professor, CKD International Nursing College, Amritsar, Punjab, India.

**Assistant Professor, CKD International Nursing College, Amritsar, Punjab, India.

DOI: http://doi.org/10.47211/tg.2020.v07i03.001

\section{ABSTRACT}

Biomedical waste or hospital waste is any kind of waste containing infectious materials. It may also include waste ass ociated with the generation of biomedical waste that visually appears to be of medical or laboratory origin (e.g. packaging, unused bandages, infusion kits etc.), as well research laboratory waste containing bio molecules or organisms that are mainly restricted from environmental release. The pre-experimental study was conducted on 40 nursing students in Chief Khalsa Diwan International Nursing College, Amritsar. Prior to structured teaching programme nursing students gave self-information and a self-structured knowledge questionnaire was used and evaluate the significant of difference between the two groups. The data obtained from study subjects was analysed and interpreted in terms of objectives and hypothesis of the study. Descriptive and inferential statistics was used for the data analysis. The study findings revealed that structured teaching programme was significantly effective in increasing the knowledge of Nursing Students of Chief Khalsa Diwan International Nursing College, Amritsar.

Key Words: Bio Medical waste Management, hospital waste.

\section{ABOUT AUTHORS:}

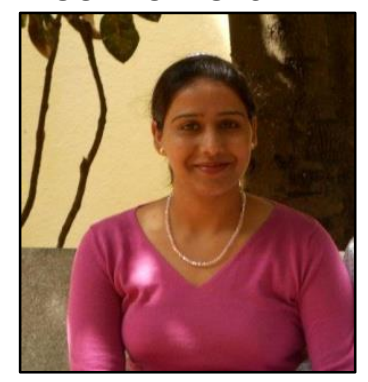

Author Dr. Mandeep Kaur is Associate Professor, CKD International Nursing College, Amritsar, Punjab, India. She is active researcher and has attended various Seminars and conferences.

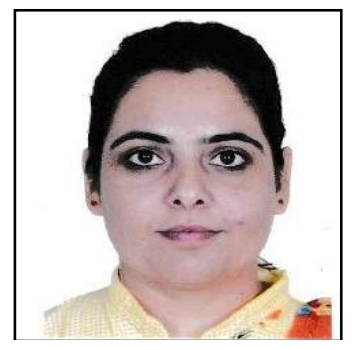

Author Ms. Kiranjit Kaur is Assistant Professor, CKD International Nursing College, Amritsar, Punjab, India. She has published various research articles in National and International Journals. 


\section{ARTICLES}

\section{INTRODUCTION:}

Earth provides enough to satisfy every man's needs, but not every man's greed (Mahatma Gandhi)

Sources of waste can be broadly classified into four types: Industrial, Commercial, Domestic, and Agricultural. And if we talk about the Types of Biomedical Waste Disposal are Autoclaving, Incineration, Chemicals and Microwaving. Waste can be classified into five types of waste which is all commonly found around the house. These include liquid waste, solid rubbish, organic waste, recyclable rubbish and hazardous waste.

Colour coding for biomedical waste management: Yellow, Red, White and Blue bins

\section{YELLOW}

- Pathological waste

- Soiled (infectious) waste

- Medical chemical waste

- Clinical lab waste

- $\quad$ Pharmaceutical waste (discarded/expired medicines and drugs)

\section{RED}

Red coloured, non-chlorinated plastic bags or containers will do the trick for waste collection. As for the disposal of such medical hazardous waste, your safest (and most practical) bet is to get your hands on an on-site sterilizer and medical waste shredder (or ISS for short).

\section{WHITE (or translucent)}

Sharps waste considering the nature of this hazardous medical waste, you will need containers that are puncturing, leak, AND tamper proof. As for disposal, the case is the same as with the waste falling under the red category: you'll need a medical waste shredder.

\section{BLUE (Medical glassware waste)}

Depending on the sources you look up, you may not even find this type of container, as some literature lists these in the same category of sharps waste, as they are also capable of inflicting puncture and cut wounds. However, since medicinal vials and ampoules aren't necessarily as hazardous as sharps waste, autoclaving may be enough to sterilize the waste, and prep it for safe disposal.

\section{NEED OF THE STUDY:}

Health care waste comprises a very small portion of the entire waste stream. It deserves attention because of the hazards it can pose to human health, if not managed properly. Waste requiring special attention includes sharps e.g. needles, scalpels and other capable of puncturing skin plastic waste, biological waste, pharmaceutical waste and variety of chemically hazardous waste used in laboratories etc.

Gehan, M.A Mostafa (2002) conducted a study to assess the knowledge \& practice related to waste management among doctors, nurses and housekeepers in the surgical department. All health care professional including nurses are highly responsible for hospital waste management. They play a leading role in managing and supervising hospital waste. They found that only $27.4 \%$ of the nurses, $36.8 \%$ of the doctors had satisfactory knowledge.

Although Bio-Medical waste management can't be achieved without the cooperation of each and every health care worker. In addition to nursing personnel's and nursing student should also be informed about the current available technology to deal with hospital waste, so we conduct the study to aims at assessing the knowledge regarding hospital waste management among the nursing students.

\section{PROBLEM STATEMENT:-}

A Pre-experimental study to assess the effectiveness of structured teaching programme on knowledge regarding bio-medical waste management among B.sc nursing students studying in selected Nursing College of Amritsar (Punjab).

\section{OBJECTIVES:}

$>$ To assess the pre-test knowledge regarding Bio- Medical Waste Management among the nursing students.

$>$ To assess the post-test knowledge regarding Bio- Medical Waste Management among the nursing students.

$>$ To assess the effectiveness of structured teaching programme regarding Bio Medical Waste among the nursing students.

> To find out the association of post-test knowledge with selected socio demographic variable such as age, gender, source of information, previous knowledge. 


\section{ARTICLES}

\section{HYPOTHESIS:}

The post-test knowledge score will be significantly higher than the pre-test knowledge score of nursing students regarding Bio Medical Waste Management at 0.05 level of significance.

\section{METHODS AND MATERIAL:}

The research approach for this study was pre-experimental conducted in Chief Khalsa Diwan International Nursing College, Chabhal Road, Amritsar among 40 B.sc nursing $1^{\text {st }}$ year students using purposive sampling technique.

The tool consisted of two sections: Section A: selected socio-demographic variables \& Section B: Self-structured questionnaire regarding Bio Medical Waste Management.

Procedure of data collection: The investigator took permission from the principal of Chief Khalsa Diwan international college of Nursing, Chabhal Road, Amritsar to carry out research study.

\section{DELIMITATION}

The study is limited to:

- The selected nursing college of Amritsar.

- 40 sample.

\section{SECTION I}

Table No. 1

Frequency and percentage distribution of sample characteristics.

\begin{tabular}{|c|c|c|c|}
\hline Sr. & Socio Demographic variable & Frequency (n) & Percentage (\%) \\
\hline \multirow[t]{4}{*}{1.} & Age(in years) & & \\
\hline & $16-18$ & 05 & $12.5 \%$ \\
\hline & $18-20$ & 33 & $82.5 \%$ \\
\hline & $21-23$ & 02 & $05 \%$ \\
\hline \multirow[t]{3}{*}{2.} & Gender & & \\
\hline & Male & 04 & $10 \%$ \\
\hline & Female & 36 & $90 \%$ \\
\hline \multirow[t]{5}{*}{3.} & Source of information & & \\
\hline & Books & 18 & $45 \%$ \\
\hline & Teacher & 19 & $47.5 \%$ \\
\hline & Mass Media & 02 & $05 \%$ \\
\hline & Peer & 01 & $2.5 \%$ \\
\hline \multirow[t]{3}{*}{4.} & Previous Knowledge & & \\
\hline & Yes & 27 & $67.5 \%$ \\
\hline & No & 13 & $32.5 \%$ \\
\hline
\end{tabular}

Table 1 depicts frequency a percentage of socio-demographic characteristics of study subjects, 40 nursing students, were to assess the knowledge regarding BMW. According to age, $12.5 \%$ nursing students were in the age group of $16-18$ years. $82.5 \%$ students were in $18-20$ years \& followed by $5 \%$ students were 21 \& above. Regarding 


\section{ARTICLES}

gender, $10 \%$ nursing students were male and $90 \%$ were female. On the other hand, the source of information $45 \%$ students were gained knowledge from books as well as $47.5 \%$ got from teachers directly and rest $5 \%$ and $2.5 \%$ gained knowledge through mass media and peer groups respectively. Moreover, $67.5 \%$ nursing students had previous knowledge and remaining $32.5 \%$ had no idea regarding this.

\section{CONCLUSION:}

- Most of the nursing students lacked prior knowledge of Bio- Medical Waste Management which was found to be increased after structured teaching programme on Bio -Medical Waste Management.

- It is evident from the overall improvement in the mean knowledge score of pre-test mean \pm SD $+2.31 \pm$ 15.73 and in the post-test mean + SD $0.85 \pm 22.13$ with' $t^{\prime}$ value of 17.9824

- Hence, the hypothesis is accepted.

\section{LIMITATIONS}

- $\quad$ The study was limited to the students who are studying in Chief Khalsa Diwan International Nursing College.

- The study was confined only 40 students.

- $\quad$ Only students were accepted to participate in the study.

\section{REFERENCES}

1. WHO: Safe management of Biomedical sharps in India. New Delhi. WHO Health care waste policy 2005.

2. Mukesh Yadav. Hospital waste. A major problem practioner, Jk -2001:8(4) 276-202

3. N. Mathur.mohidem. Hospital Waste Management. A burning problem. Nightingale Nursing Team 2007:3 (3). 21-23.

4. Anand R.C and Sidharth Saith Pathy, Hospital waste management, A holistic, New Delhi-jaypee brother, meical publishers page no 48

5. Madhri Sharma, Hospital Waste Management and its monitoring its edition, Jayoee Publication P.No -2-5.

6. Bio Mesical Waste management and handing rules 1998, http//www.mppcb.nic.in/biomedicalwaste.hyml.

7. Ministry of environment and forests notification http;infor.nic.in/legis/hsm/biomed.html.

8. Segregation of waste amendment of bio medical waste management http;www.gooogle.co.in/ imgresammendment- biomedical waste management.

9. Govt. of India, Ministry of environment and forests bio medical waste management available from http;envfor.nic/legis/hsm/bio mmed.html. 